\title{
THE PRESENCE OF
}

\section{HELICOBACTER PYLORI IN} POSTMENOPAUSAL WOMEN IS NOT A FACTOR TO THE DECREASE OF BONE MINERAL DENSITY

\author{
Adriana M. KAKEHASI ${ }^{1}$,Cláudia M. C. MENDES², Luiz G. V. COELHO², Luiz P. CASTRO² and \\ Alfredo J. A. BARBOSA ${ }^{1,2}$
}

\begin{abstract}
Background - Osteoporosis affects approximately 30\% of postmenopausal women. Gastrectomy, pernicious anemia, and more recently Helicobacter pylori infection, have all been implicated in the pathogenesis of osteoporosis. A reduced parietal cell mass is a common feature in these conditions. Aim - To study a possible relationship between chronic gastritis, parietal cell density of the oxyntic mucosa and bone mineral density in postmenopausal women, as chronic gastritis, Helicobacter pylori infection and osteoporosis are frequently observed in the elderly. Methods - Fifty postmenopausal women (61.7 \pm 7 years) were submitted to gastroduodenal endoscopy and bone densitometry by dual energy X-ray absorptiometry. Glandular atrophy was evaluated objectively by the determination of parietal cell density. Helicobacter pylori infection was evaluated by histology, urease test and breath test with ${ }^{13} \mathrm{C}$. Results - Thirty-two patients (64\%) presented chronic multifocal gastritis, and 20 of them (40\%) showed signs of gastric mucosa atrophy. Lumbar spine osteoporosis was found in 18 patients (36\%). The parietal cell density in patients with and without osteoporosis was $948 \pm 188$ and $804 \pm 203$ cells $/ \mathrm{mm}^{2}$, respectively. Ten osteoporotic patients (55\%) and 24 non-osteoporotic patients (75\%) were infected by Helicobacter pylori. Conclusion - Postmenopausal women with osteoporosis presented a well-preserved parietal cell density in comparison with their counterparts without osteoporosis. Helicobacter pylori infection was not different between the two groups. We concluded that neither atrophic chronic gastritis nor Helicobacter pylori seem to be a reliable risk factor to osteoporosis in postmenopausal women.
\end{abstract}

HEADINGS - Postmenopause. Osteoporosis, postmenopausal. Gastritis. Helicobacter infections.

\section{INTRODUCTION}

Osteoporosis is characterized by low bone mass and micro architectural deterioration of the skeleton, leading to enhanced risk of fractures. One of the most important factors that determines the development of osteoporosis and explains its prevalence in females is the estrogen deficiency occurring in the postmenopausal period ${ }^{(36)}$. Besides, other risk factors are involved such as age-related conditions, genetic background, environmental pitfalls, chronic diseases, and physical characteristics of bone. Among gastrointestinal diseases inflammatory bowel disease, celiac disease and gastrectomy are associated with osteoporosis ${ }^{(3,7,13,24,25,30)}$. Gastrectomy is recognized as a risk factor for osteoporosis and patients submitted to this surgical procedure present a higher incidence of fractures ${ }^{(4,26,40)}$. It has been attributed to long-standing calcium deficiency due to hypochlorhydria, since acid is thought to be necessary to dietary calcium absorption $^{(4,26,34,40)}$. In addition, experimental studies have shown evidence of the presence of a hypocalcemic factor produced by gastric oxyntic mucosa ${ }^{(12)}$. This putative peptidergic hormone, a leucine aminopeptidasesensitive factor namely gastrocalcin, could act on bone metabolism since the administration of extracts of the oxyntic mucosa prevented bone loss in gastrectomized animals, independently of calcium replacement ${ }^{(31)}$.

Chronic gastritis is a common disease in the general population and one of its consequences is gastric glandular atrophy, which is more prevalent in the elderly ${ }^{(21)}$. In postmenopausal women, glandular atrophy could be associated with metabolic bone disorders due either to hypochlorhydria or derangement of gastric hormonal homeostasis. The objective of the present investigation was to study the presence of chronic gastritis, the degree of glandular atrophy of the oxyntic mucosa, Helicobacter pylori (Hp) infection, and bone mineral density in postmenopausal women.

'Laboratory of Digestive and Neuroendocrine Pathology; ${ }^{2}$ Alfa Institute of Gastroenterology, Federal University of Minas Gerais School of Medicine, Belo Horizonte, MG, Brazil. Correspondence: Dr. Alfredo J. A. Barbosa - Faculdade de Medicina UFMG - Av. Prof. Alfredo Balena, 190 - 30130-100 - Belo Horizonte, MG, Brazil. E-mail: abarbosa@ medicina.ufmg.br 


\section{METHODS}

\section{Subjects}

A cross-sectional study of 50 women with at least 5 years in the postmenopausal period ( $>49$ year-old) and without hormonal replacement therapy, were performed. Conditions that could interfere with the evaluation of either osteoporosis or gastric mucosa damage were adopted as exclusion criteria: (a) therapy for or to prevent osteopenia; (b) history of thyroid, renal or gastrointestinal disorders; (c) use of anticonvulsants, corticosteroids, nonsteroidal anti-inflammatory drugs, histamine $\mathrm{H}_{2}$-receptor antagonist and proton pump inhibitor drugs, and (d) alcoholism.

\section{Histology}

Patients were submitted to gastroduodenal endoscopy by the same professional (CMCM) and tissue samples were collected from four sites of the oxyntic mucosa, and from two sites of the antral mucosa as determined in the study protocol. Paraffin sections were submitted to: (a) hematoxylineosin (H-E) staining for histology; (b) Grimelius staining for argyrophil cells (endocrine cells) ${ }^{(11)}$, (c) Giemsa staining for $\mathrm{Hp}$, and (d) immunoperoxidase staining for the demonstration of parietal cells (PC) using a specific monoclonal antibody against PC secretory membranes ${ }^{(1,9)}$. The following items were evaluated separately: intensity and distribution of inflammatory cells in antral and oxyntic mucosa, and glandular atrophy scored from slight to moderate/severe. $\mathrm{Hp}$ infection was evaluated by histology in Giemsa-stained slides and breath test with ${ }^{13} \mathrm{C}$. The mean density of $\mathrm{PC}$ $\left(\mathrm{PC} / \mathrm{mm}^{2}\right)$ throughout the full mucosa thickness was used to score objectively the presence and the degree of glandular atrophy in oxyntic mucosa.

Using a microscopic reticulum-coupled eyepiece (200 $\mu \mathrm{m}$ x $200 \mu \mathrm{m}$ at $400 \mathrm{x}$ magnification), parietal and argyrophil cells were counted along three to six columns of the oxyntic mucosa sections containing the full mucosa thickness. The final results were expressed in number cells $/ \mathrm{mm}^{2}$. Cells were considered to be parietal and argyrophil when their cytoplasm was clearly stained and contrasted, with negative surrounding elements, regardless of the presence of the nucleus.

\section{Bone mineral density and laboratory assessment}

Lumbar spine mineral density was determined by dual energy X-ray absorptiometry (GE Medical System, Lunar Radiation Corp., Madison, WI, USA). This examination was carried out using the same densitometer and always analyzed by the same radiologist. Bone mineral density was expressed both as $\mathrm{g} / \mathrm{cm}^{2}$ and as percentage related to age- and sex-matched controls. The diagnosis of osteoporosis was considered according to WHO criteria, represented by a T-score of $\leq-2.5$ and compared with a peak bone density in young adults ${ }^{(17)}$. Blood samples were obtained for blood cell count and for the determination of the presence of PC antibodies, and serum concentrations of calcium, phosphorus, bone-specific alkaline phosphatase activity, and parathyroid hormone.

\section{Statistical analysis and ethics}

Student's $t$ test, linear regression, and multiple stepwise regression analyses were applied. The study protocol was approved by the Ethics Committee of the Federal University of Minas Gerais (Belo Horizonte, MG, Brazil) and informed consent was obtained from all patients at the time of inclusion in the study.

\section{RESULTS}

\section{Patients}

Fifty female patients, mean age $61.6 \pm 7$ y (range 50-79 y), two African-Brazilians, and 48 Caucasians, with a mean climacteric period of $12.7 \pm 8 \mathrm{y}$ were included in this study. The mean body mass index $\left(\mathrm{kg} / \mathrm{m}^{2}\right)$ of the patients was 27.3 \pm 4.5 . Six $(12 \%)$ patients presented a history of previous fractures and seven (14\%) had a family antecedent of osteoporosis. None of the patients had serum antibodies against $\mathrm{PC}$ or alterations in serum levels of calcium, phosphorus, vitamin $B_{12}$, parathyroid hormone, or bone specific alkaline phosphatase.

\section{Histology and Hp infection}

The gastric mucosa showed: (a) normal histology or minimal inflammatory changes in 11 patients; (b) predominantly antral chronic gastritis, with normal or nearly normal oxyntic mucosa in 7 patients, and (c) chronic pangastritis in 32 patients. Among patients with pangastritis, 10 presented moderate or severe glandular atrophy, 10 presented mild glandular atrophy, and 12 had no histological evidence of glandular atrophy. Therefore, $30(60 \%)$ patients had no histological signs of patent gastric glandular atrophy independently of the presence of an inflammatory infiltrate in the lamina propria. Thirty-four $(68 \%)$ patients were positive for $H$. pylori. The results of histology and Hp infection are summarized in Table 1.

TABLE 1. Correlation between the histopathological diagnosis of gastric mucosa atrophy, Helicobacter pylori infection, and the parietal cell (PC) density in 50 postmenopausal women

\begin{tabular}{lccc}
\hline Histopathology & $\mathrm{n}(\%)$ & $\mathrm{Hp} \mathrm{positive}^{\dagger}(\%)$ & $\mathrm{PC} / \mathrm{mm}^{2 *}$ \\
\hline $\begin{array}{l}\text { Normal (11) or chronic gastritis } \\
\text { without atrophy (19) }\end{array}$ & $30(60)$ & $16(53)$ & $948 \pm 152$ \\
$\begin{array}{l}\text { Chronic gastritis with mild atrophy } \\
\begin{array}{l}\text { Chronic gastritis with moderate/ } \\
\text { severe atrophy }\end{array}\end{array}$ & $10(20)$ & $9(90)$ & $816 \pm 157$ \\
\hline
\end{tabular}

$\dagger$ All patients Hp positive had chronic gastritis
$* P<0.001$

\section{PC density}

The mean PC density was $855 \pm 208 \mathrm{PC} / \mathrm{mm}^{2}$ for the 50 patients as a whole and $948 \pm 152 \mathrm{PC} / \mathrm{mm}^{2}$ for the 30 patients without histological glandular atrophy. The mean PC density was $816 \pm 157 \mathrm{PC} / \mathrm{mm}^{2}$ in patients with mild glandular atrophy, and $618 \pm 208 \mathrm{PC} / \mathrm{mm}^{2}$ in those with moderate/severe glandular atrophy (Table 1). The difference in PC density between these three groups was statistically significant $(P<0.001)$. 


\section{Endocrine cell density}

The mean endocrine cell (EnC) density was $179 \pm 80 \mathrm{EnC} / \mathrm{mm}^{2}$ for the 50 patients as a whole and $183 \pm 91 \mathrm{EnC} / \mathrm{mm}^{2}$ for those with normal gastric mucosa. EnC densities were lower in patients with mucosa atrophy: $199 \pm 67 \mathrm{EnC} / \mathrm{mm}^{2}$, and $144 \pm$ $43 \mathrm{EnC} / \mathrm{mm}^{2}$, respectively, in patients with mild and moderate/ severe glandular atrophy, but this difference did not reach statistical significance $(P>0.05)$.

\section{Bone mineral density, gastric mucosa atrophy and Hp infection}

Lumbar spine osteoporosis was detected in $18(36 \%)$ patients and osteopenia in $21(42 \%)$. Eleven $(22 \%)$ patients had normal bone mineral density. Patients were divided into two groups, with and without osteoporosis, the latter including both normal and osteopenic patients. These two groups did not differ from one another in terms of mean age, body mass index, age at menarche, or postmenopausal period (Table 2). Chronic gastritis was present in 10 osteoporotic patients $(31 \%)$ and in 22 non-osteoporotic patients $(69 \%)(P=0.71)$. The mean PC density of the oxyntic mucosa was $948 \pm 188 \mathrm{PC} / \mathrm{mm}^{2}$ in patients with osteoporosis and $804 \pm 203 \mathrm{PC} / \mathrm{mm}^{2}$ in patients without osteoporosis $(P=0.038)$. In addition, the mean EnC density was $190 \pm 101 \mathrm{EnC} / \mathrm{mm}^{2}$ in osteoporotic women and $173 \pm$ $66 \mathrm{EnC} / \mathrm{mm}^{2}$ in non-osteoporotic women $(P=0.49)$. The prevalence of Hp infection was $55 \%(10 / 18)$ and $75 \%(24 / 32)$ in patients with and without osteoporosis, respectively $(P=0.22)$. Results are summarized in Table 3.

TABLE 2. Clinical characteristics of 50 postmenopausal women according to the presence of lumbar spine osteoporosis. Data are presented as mean

\begin{tabular}{lccc}
\hline Characteristic & Osteoporosis $(\mathrm{n}=18)$ & Normal/osteopenia $(\mathrm{n}=32)$ & $P$ \\
\hline Age (years) & 62 & 61 & NS \\
Body mass index (kg/m2) & 27 & 26 & NS \\
Age at menarche (years) & 16 & 13 & NS \\
Menopause (years) & 13 & 12 & NS \\
\hline
\end{tabular}

NS $=$ Not significant

TABLE 3. Parietal cell (PC) density, endocrine cell (EnC) density, and $H$. pylori infection according to the presence of lumbar spine osteoporosis in 50 postmenopausal women

\begin{tabular}{lcccc}
\hline $\begin{array}{l}\text { Bone mineral } \\
\text { density }\end{array}$ & $\mathrm{n}(\%)$ & $\begin{array}{c}\text { Parietal cells } \\
\left(\mathrm{PC} / \mathrm{mm}^{2}\right)^{*}\end{array}$ & $\begin{array}{c}\text { Endocrine cells } \\
\left(\mathrm{EnC} / \mathrm{mm}^{2}\right)^{* *}\end{array}$ & H. pylori $+(\%)^{* *}$ \\
\hline Normal/osteopenia & $32(64)$ & $804 \pm 203$ & $173 \pm 66$ & $24(75)$ \\
Osteoporosis & $18(36)$ & $948 \pm 188$ & $190 \pm 101$ & $10(55)$ \\
\hline
\end{tabular}

* $P=0.038$

** not significant

\section{DISCUSSION}

Osteoporosis, characterized by low bone mass, is the most prevalent metabolic bone disease and an important health threat in the elderly, mainly in postmenopausal women. Decreased bone mass results in an increased risk of fractures, which are the sole clinical manifestation of this pathological condition. Vertebrae, hip, and forearm, are the most common sites of fractures, which occur in approximately $30 \%$ of postmenopausal women ${ }^{(16,27)}$. Bone mineral content and density are relatively constant in adult men and women under the age of 50 years. The enhanced bone loss that occurs thereafter coincides with ovarian failure shortly before menopause and continues throughout life, causing primary osteoporosis ${ }^{(8,18)}$. Besides estrogen deficiency, a variety of different factors could lead to secondary bone loss (secondary osteoporosis) such as primary hyperparathyroidism, corticosteroid therapy, prolonged immobilization, chronic obstructive lung disease, and gastrointestinal and hepatobiliary disorders ${ }^{(2,28,38)}$.

It has been recognized that patients submitted to gastrectomy have lower bone mineral density and an increased risk of fractures when compared to healthy subjects ${ }^{(4,26,35,40)}$. In gastrectomized patients calcium absorption deficiency could be the result of the established hypochlorhydria since gastric acid mobilizes calcium from insoluble complexes, facilitating its absorption ${ }^{(5,14)}$. This suggests an important role for the acid secretory capacity of the stomach in maintaining bone calcium balance. In spite of the importance of gastrectomy-induced osteoporosis, very little is known about the influence of the gastric mucosa on bone metabolism. Since the experimental studies of IVY ${ }^{(15)}$, who described bone loss in gastrectomized dogs, many studies have demonstrated that the gastric mucosa is related in some way to the incorporation of calcium into bone $^{(19,20,23,31,32,37)}$. Despite the accepted role of gastric acid secretion in maintaining calcium absorption, the treatment of rats with a potent proton pump inhibitor resulting in almost complete achlorhydria had no effect on bone density, and, in addition, parenteral calcium supplementation did not prevent bone mineral loss in gastrectomized animals ${ }^{(32)}$. This indicates that the stomach could be an important organ related to calcium homeostasis but not through its acid secretory activity.

Because osteoporosis is a prevalent condition among postmenopausal women and considering that $\mathrm{Hp}$ and atrophic gastritis are a relatively common finding in the elderly, we undertook this investigation to study a possible relationship between bone mineral density, atrophic gastritis, and $\mathrm{Hp}$ infection. An epidemiologic study using a serologic diagnosis of Hp infection showed an increased prevalence of this bacterium in male subjects presenting osteoporosis ${ }^{(10,29)}$. Nevertheless, the present results indicate that neither Hp infection nor atrophic gastritis appear to be relevant as possible factors contributing to the development of primary osteoporosis in postmenopausal women.

The gastric acid secretory capacity is known to be directly related to parietal cell mass ${ }^{(6,39)}$. The objective evaluation of parietal cell density was in accordance with histological found of oxyntic mucosa atrophy, and our results showed that patients with osteoporosis had parietal cell mass better preserved than the non-osteoporotic ones. This finding indicates that the expected lower gastric acid secretion in chronic atrophic gastritis may not be relevant as a factor contributing to osteoporosis in postmenopausal women. Another possibility is that moderate or discrete levels of acid secretion would be enough to maintain reasonable calcium absorption throughout the small intestine. 
This finding would be relevant concerning human pathology because aging is strongly linked to the presence of chronic gastritis with variable degrees of mucosal atrophy. It is known that most of the gastric mucosa changes are linked to Hp infection, which causes recruitment of inflammatory cells to the gastric mucosa and increases the rate of development of gastric atrophy ${ }^{(21,22)}$. In addition, the presence of this microorganism could lead to an imbalance of gastric hormones, as described for gastrin and somatostatin in duodenal ulcer patients ${ }^{(33)}$. Using an argyrophil technique we were not able to detect any significant difference in endocrine cell densities between patients with and without osteoporosis. In fact, the endocrine cell density, although not significant, was lower in non-osteoporotic subjects, probably as a consequence of the atrophic changes of the gastric mucosa observed more frequently in these patients.

\section{CONCLUSION}

We conclude that most of the postmenopausal women with osteoporosis presented well-preserved glandular components of the oxyntic mucosa. Hp infection with or without chronic atrophic gastritis, seems to be not an important factor related to the decreased bone mineral density in this specific group of postmenopausal women.

\section{ACKNOWLEDGEMENTS}

This work was supported by "Conselho Nacional de Desenvolvimento Científico e Tecnológico" (CNPq), Brasília, DF. Authors thank Dr. Eugênio Marcos Andrade Goulart for helpful assistance on statistical analysis.

Kakehasi AM, Mendes CMC, Coelho LGV, Castro LP, Barbosa AJA. A presença do Helicobacter pylori em mulheres na pós-menopausa não constitui fator de risco para a diminuição da densidade mineral óssea. Arq Gastroenterol. 2007;44(3):266-70.

RESUMO - Racional - A osteoporose afeta aproximadamente 30\% das mulheres na pós-menopausa. Gastrectomia, anemia perniciosa e mais recentemente, a infecção pelo H. pylori, têm sido implicados na patogênese da osteoporose. A diminuição da massa de células parietais constitui aspecto comum a estas condições. Objetivos - Estudar possível relação entre gastrite crônica, densidade de células parietais da mucosa oxíntica e a densidade mineral óssea em mulheres na pós-menopausa. Métodos - Cinqüenta mulheres na pós-menopausa (média de idade $61.7 \pm 7$ anos) foram submetidas a endoscopia digestiva alta e a densitometria óssea pela absorciometria com raio-X de dupla energia. A atrofia glandular foi avaliada, histologicamente e pela determinação da densidade das células parietais na mucosa do corpo gástrico. A infecção pelo H. pylori foi avaliada através da histologia, teste da urease e teste respiratório com $\mathrm{C}^{13}$. Resultados - Trinta e dois pacientes (64\%) apresentaram gastrite crônica e 20 (40\%) deles apresentaram sinais de atrofia de mucosa gástrica através da análise histopatológica rotineira. Osteoporose da coluna lombar foi encontrada em 18 (36\%) pacientes. A densidade de células parietais em pacientes com e sem osteoporose foi $948 \pm 188$ e $804 \pm 2003$ células $/ \mathrm{mm}^{2}$, respectivamente. Dez pacientes (55\%) com osteoporose e $24 \%$ (75\%) pacientes sem osteoporose estavam infectados pelo H. pylori. Conclusão - Mulheres na pós-menopausa com osteoporose apresentaram mucosa gástrica e população de células parietais mais conservadas em relação àquelas sem osteoporose. A infecção pelo H.pylori não foi estatisticamente diferente entre mulheres com e sem osteoporose, indicando que a infecção por esta bactéria, com ou sem atrofia da mucosa gástrica, não se constitui em fator de risco para osteoporose em mulheres na pós-menopausa.

DESCRITORES - Pós-menopausa. Osteoporose pós-menopausa. Gastrite. Infecções por Helicobacter. 


\section{REFERENCES}

1. Barbosa AJ, Mendes CM, Coelho LG, Rodrigues CB, Machado MM, Castro LP. Increased parietal cell density in patients with perforated duodenal ulcer: comparison with non-complicated duodenal ulcer patients. Gastroenterology. 2001;120:A1300.

2. Bauer DC, Browner WS, Cauley JA, Orwoll ES, Scott JC, Black DM, Tao JL, Cummings SR. Factors associated with appendicular bone mass in older women. The study of osteoporotic fractures research group. Ann Intern Med. 1993;118:657-65.

3. Bernstein CN, Leslie WD, Leboff MS. AGA technical review on osteoporosis in gastrointestinal diseases. Gastroenterology. 2003;124:795-841.

4. Bisballe S, Eriksen EF, Melsen F, Mosekilde L, Sorensen OH, Hessov I. Osteopenia and osteomalacia after gastrectomy: interrelations between biochemical markers of bone remodeling, vitamin D metabolites, and bone histomorphometry. Gut 1991;32:1303-7.

5. Bo-Linn GW, Davis GR, Buddrus DJ, Morawski SG, Santa Ana C, Fordtran JS. An evaluation of the importance of gastric acid secretion in the absorption of dietary calcium. J Clin Invest. 1984;73:640-7.

6. Card WI, Marks IN. The relationship between acid output of the stomach following "maximal" histamine stimulation and the parietal cell mass. Clin Sci. 1960;19:147-63.

7. Compston JE, Judd D, Crawley E, Evans WD, Evans C, Church HA, Reid EM, Rhodes J. Osteoporosis in patients with inflammatory bowel disease. Gut. 1987; 28:410-5.

8. Favus MI. Primer on the metabolic bone diseases and disorders of mineral metabolism. Philadelphia: Lippincott-Raven;1996.

9. Ferreira RC, Barbosa AJA, Gonçalves VF, Martins MS, Rodrigues CB, Sato PR, Nogueira JC. Parietal cell/endocrine cell ratio in the oxyntic mucosa of some species of mammals. Acta Microscopica. 1999;8(Suppl B):169-70.

10. Figura N, Gennari L, Merlotti D, Lenzi C, Campagna S, Franci B, Lucani B, Trabalzini L, Biancardi L, Gonnelli C, Santucci A, Nut A. Prevalence of Helicobacter pylori infection in male patients with osteoporosis and controls. Dig Dis Sci. 2005;50:847-52.

11. Grimelius L. A silver nitrate stain for alpha-2 cells in human pancreatic islets. Acta Soc Med Ups. 1968;73:243-70.

12. Håkanson R, Persson P, Axelson J, Johnell O, Sundler F. Evidence that gastrin enhances ${ }^{45} \mathrm{Ca}$ uptake into bone through release of a gastric hormone. Regul Pept. 1990;28:107-18

13. Honasoge M, Rao DS. Metabolic bone disease in gastrointestinal, hepatobiliary, and pancreatic disorders and total parenteral nutrition. Curr Opin Rheumatol. 1995; 7:249-54

14. Ivanovich P, Fellows $\mathrm{H}$, Rich $\mathrm{C}$. The absorption of calcium carbonate. Ann Intern Med. 1967;66:917-23.

15. Ivy AC. The effect of gastrectomy in animals. Am J Dig Dis. 1940;7:500-2.

16. Kanis JA, Delmas P, Burckhardt P, Cooper C, Torgerson D. Guidelines for diagnosis and management of osteoporosis. The European Foundation for Osteoporosis and Bone Disease. Osteopor Int. 1997;7:390-406.

17. Kanis JA, Melton LJ, $3^{\text {rd }}$ Christiansen C, Johnston CC, Khaltaev N. The diagnosis of osteoporosis. J Bone Miner Res. 1994;9:1137-41.

18. Kanis JA, Pitt FA. Epidemiology of osteoporosis. Bone. 1992;13:s7-s15.

19. Kaplan EL, Norberg HP, Schulack JA, Hill BJ. The importance of the stomach in mediating histamine-induced hypocalcemia in the rat. Metabolism. 1976;25:1151-6.

20. Kaplan EL, North PT, Norberg HP, Schulack JA, Hill BJ. Evidence for a role of the stomach in serum calcium regulation. J Surg Res. 1977;22:237-41.
21. Kuipers EJ, Uyterlinde AM, Pena AS, Roosendaal R, Pals G, Nelis GF, Festen HP, Meuwissen SG. Long-term sequelae of Helicobacter pylori gastritis. Lancet. 1995;345:1525-8.

22. Lamarque D, Tran Van Nhieu J, Breban M. What are the gastric modifications induced by acute and chronic Helicobacter pylori infection? Gastroenterol Clin Biol. 2003;27:391-400

23. Limlomwongse L, Krishnamra N. The mechanism of action and target organ of gastrin-induced hypocalcemia. Proc Soc Exp Biol Med. 1981;168:72-6.

24. Lora FL, Amarante HM, Pisani JC, Borba VVC, Kulak CA, Carmes ER. Avaliação da densidade mineral óssea em pacientes com doença inflamatória intestinal. Arq Gastroenterol. 2005;42:201-5.

25. McFarlane X, Bhalla A, Reeves D, Morgan LM, Robertson DA. Osteoporosis in treated adult celiac disease. Gut. 1995;36:710-4

26. Mellstrom D, Johansson C, Johnell O, Lindstedt G, Lundberg PA, Obrant K, Schoon IM, Toss G, Ytterberg BO. Osteoporosis, metabolic aberrations, and increased risk for vertebral fractures after partial gastrectomy. Calcif Tissue Int. 1993;53:370-7.

27. Melton LJ, $3^{\text {rd }}$, Kan SH, Frye MA, Wahner HW, O'Fallon WM, Riggs BL. Epidemiology of vertebral fracture in women. Am J Epidemiol. 1989;129:1000-11.

28. Melton LJ, $3^{\text {rd }}$, Atkinson EJ, Khosla S, O'Fallon WM, Riggs BL. Secondary osteoporosis and the risk of vertebral deformities in women. Bone 1999;24:49-55.

29. Nielsen H, Langdahl BL, Hansen JM, Moller M, Ostergaard L. Helicobacter pylori seropositivity is increased in osteoporosis. Gut. 2001;47(Suppl 1):a89-a90.

30. Paakkonen M, Alhava EM, Karjalainen P, Korhonen R, Savolainen K, Syrjanen K. Long-term follow-up after Billroth I and II partial gastrectomy. Gastrointestinal tract function and changes in bone metabolism. Acta Chir Scand. 1984;150:485-8.

31. Persson P, Håkanson R, Axelson J, Sundler F. Gastrin releases a blood calcium-lowering peptide from the acid-producing part of the rat stomach. Proc Natl Acad Sci USA 1989;86:2834-8.

32. Persson P, Gagnemo-Persson R, Chen D, Axelson J, Nylander AG, Johnell O, Hakanson $\mathrm{R}$. Gastrectomy causes bone loss in the rat: is lack of gastric acid responsible? Scand J Gastroenterol. 1993;28:301-6.

33. Queiroz DM, Mendes EN, Rocha GA, Moura SB, Resende LM, Barbosa JA, Coelho LG, Passos MC, Castro LP, Oliveira CA. Effect of Helicobacter pylori eradication on antral gastrin- and somatostatin-immunoreactive cell density and gastrin and somatostatin concentrations. Scand J Gastroenterol. 1993;28:858-64.

34. Recker RR. Calcium absorption and achlorhydria. N Engl J Med. 1985;313:70-3.

35. Rejman F. Postgastrectomy syndrome. A clinical study based upon 100 patients. Ann Chir Gynaecol Fenn Suppl. 1970;170:1-63.

36. Riggs BL, Khosla S, Melton LJ, $3^{\text {rd }}$. A unitary model for involutional osteoporosis: estrogen deficiency causes both type I and type II osteoporosis in postmenopausal women and contributes to bone loss in aging men. J Bone Miner Res. 1998;13:763-73.

37. Schulak JA, Kaplan EL. The importance of the stomach in gastrin-induced hypocalcemia in the rat. Endocrinology. 1975;96:1217-20.

38. Southerland JC, Valentine JF. Osteopenia and osteoporosis in gastrointestinal diseases: diagnosis and treatment. Curr Gastroenterol Rep. 2001;3:399-407.

39. Tongen LA. The quantitative relationship between parietal cells and gastric acidity. Surgery. 1950;28:1009-15.

40. Zittel TT, Zeeb B, Maier GW, Kaiser GW, Zwirner M, Liebich H, Starlinger M, Becker HD. High prevalence of bone disorders after gastrectomy. Am J Surg. 1997; 174:431-8.

Recebido em 20/9/2006. Aprovado em 10/5/2007. 